\title{
Cooking of meat: effect on texture, cooking loss and microbiological quality - a review
}

\author{
František Ježek ${ }^{1}$, Josef Kameník², Blanka Macharáčková2, Kateřina Bogdanovičová2, \\ Jiří Bednáŕr
}

\begin{abstract}
University of Veterinary and Pharmaceutical Sciences Brno,
Faculty of Veterinary Hygiene and Ecology, ${ }^{1}$ Department of Meat Hygiene and Technology, ${ }^{2}$ Department of Gastronomy
\end{abstract}

Received October 4, 2019

Accepted November 26, 2019

\begin{abstract}
Cooking can positively affect meat tenderness, on the other hand, the heat treatment also causes weight loss. The resulting tenderness of cooked meat is influenced by the background toughness of fresh meat, by the post mortem ageing process and by the method of cooking. In the case of heat treatment, the temperature and duration of action play a key role. In this respect, the meat tenderness depends on the type of appliance used for cooking. The cooking loss of meat during heat treatment is caused by contraction of muscle fibres and intramuscular connective tissue, the intensity of which also depends on the temperature and device used. The extent of this contraction increases with increasing temperature. Cooking of meat is considered the most effective way of eliminating microorganisms causing food-borne diseases. The recommended combination of temperature and time of $70^{\circ} \mathrm{C}$ for 2 min reduces the number of Listeria monocytogenes bacteria by more than $6 \log$. This temperature is not, however, always attained with the use of many meat cooking methods, such as grilling or frying. This presents the risk of survival of food-borne agents. The latest knowledge indicates that, in the case of cross contamination, the population of food-borne agents is of the order of $1-2 \log \mathrm{CFU} / \mathrm{cm}^{2}$ or g. If they do not multiply as a result of a higher environmental temperature, the population of pathogenic bacteria present is then reliably eliminated during adequate cooking, either entirely or to an amount that does not suffice to induce illness.
\end{abstract}

Shear force, heat treatment, Salmonella spp., Listeria monocytogenes, STEC

Humans have been cooking meat for hundreds of thousands of years to improve its digestibility and modify its sensory properties. Tenderness is one of the most highly valued characteristics of meat after cooking (Archile-Contreras et al. 2010; Aaslyng et al. 2018; Fabre et al. 2018; Li et al. 2019).

Tenderness is a highly variable attribute of meat that is influenced by a number of factors (Dominguez-Hernandez et al. 2018). These include the anatomical-histological structure of individual muscles expressed by the mutual proportions of various types of muscle fibres and the formation of the perimysium - a connective tissue sheath surrounding muscle bundles. In addition to the structure of the muscle itself, the tenderness of fresh meat is also influenced by post mortem processes during the "ageing" of meat (Hulánková et al. 2018). The final tenderness of cooked meat is, of course, also influenced by the method of meat preparation, i.e. the appliance used and the intensity of cooking (the temperature and the length of its action).

Cooking of meat is considered the most effective way of eliminating microorganisms causing food-borne diseases (de Jonge 2019). Nevertheless, at least $30 \%$ of consumers do not cook meat in an adequate manner (Roccato et al. 2015). It is generally accepted that when meat (including hamburgers or any other comminuted meat) is subjected to a core temperature of $70^{\circ} \mathrm{C}$ for $2 \mathrm{~min}$ or was subjected to a heat treatment equivalent to 2 min at $70^{\circ} \mathrm{C}$, it will accomplish a substantial inactivation (6 log reduction) of pathogens (Lahou et al. 2015).

Address for correspondence:

Kateřina Bogdanovičová

Department of Gastronomy, Faculty of Veterinary Hygiene

University of Veterinary and Pharmaceutical Sciences

Palackého tř. 1946/1, 61242 Brno, Czech Republic 
In the following text the factors influencing sensory properties, weight losses and the microbiological state of meat following cooking will be analysed in detail on the basis of the latest scientific studies. The term meat is understood here as the skeletal muscle of slaughtered animals, which corresponds to the definition "fresh meat" according to European food law (Regulation (EC) No 853/2004).

\section{Meat tenderness and muscle type}

The structure of a skeletal muscle determines its background toughness (BT), which represents a constant value given at the moment of slaughter and which is defined by the arrangement and quantity of connective tissue in the muscle (Archile-Contreras et al. 2010; Veiseth-Kent et al. 2018). The quantity of intramuscular fat (IMF) (Aaslyng et al. 2018) is also used in this regard. Background toughness corresponds to the differing toughness or tenderness of various anatomical muscles within a single carcass. The most variable component of intramuscular connective tissue (IMCT) is the perimysium (Latorre et al. 2018). The toughness of muscles increases with the increasing age of animals as a result of the greater stability of the crosslinks between collagen molecules in the IMCT (Archile-Contreras et al. 2010).

In addition to BT, the tenderness of fresh meat is further determined by two phases that take place in skeletal muscle post mortem - the toughening phase and the tenderisation phase. Shortening of the sarcomere occurs during the toughening phase with the onset and progression of rigor mortis. If the sarcomere is shortened to a length below $2 \mu \mathrm{m}$, a strong negative relationship appears between the sarcomere length (SL) and the toughness of the meat (Veiseth-Kent et al. 2018). The tenderisation phase is associated with proteolysis of the main proteins (during the meat ageing phase) maintaining the structural integrity of the myofibrils (Hulánková et al. 2018).

In their study, Veiseth-Kent et al. (2018) analysed four muscles (biceps femoris/BF, infraspinatus/IS, longissimus lumborum/LL and psoas major/PM) obtained from 22 steers of four different groups of breeds slaughtered at an age of around 23 months. The parameters evaluated included the Warner-Bratzler (W-B) shear force (evaluating the toughness of the meat), SL, the proportion of IMF and the $\mathrm{pH}$ value during $48 \mathrm{~h}$ post mortem.

The toughest muscle 13 days after slaughter was the LL (sirloin). The longest sarcomere was measured in tenderloin (m. psoas major, PM; $3.64 \mu \mathrm{m}$ ), the shortest in silverside (m. biceps femoris; $1.84 \mu \mathrm{m}$ ) and sirloin (m. longissimus lumborum; $1.85 \mu \mathrm{m}$ ). The authors found the lowest proportion of IMF in the BF and LL muscles; the largest one in the IS and PM muscles.

Differences in the proportions of IMF and in SL explain the low values of the WarnerBratzler test in IS and PM muscles (i.e. their tenderness), though they could not account for the differences $(P<0.001)$ in the values of the $\mathrm{W}$-B shear force test between the sirloin (LL) and silverside (BF) muscles, as the two muscles showed similar proportions of IMF and the differences between the two muscles were likewise not significant in terms of SL. Aaslyng et al. (2018) demonstrated a positive relationship between the IMF content and meat tenderness on the basis of analyses of pork meat (m. longissimus thoracis et lumborum).

Proteolysis of key myofibrillar proteins caused by calpains plays the principal role in the process of meat tenderisation during cold storage (Huff-Lonergan et al. 2010). The activity of calpains differs in various muscles. The LL muscles generally show higher activity than the BF or PM muscles. The rapid fall in $\mathrm{pH}$ values post mortem is associated with early autolysis of calpain- 1 and a loss of proteolytic activity. The result is reduced degradation of myofibrillar proteins.

In the cited study (Veiseth-Kent et al. 2018) an accelerated fall in $\mathrm{pH}$ values was evident in PM, though this did not lead to lower proteolysis of troponin $\mathrm{T}$ in comparison 
with LL and BF muscles with a slower reduction in $\mathrm{pH}$. The level of degradation of troponin $\mathrm{T}$ in these three muscles was similar both 2 and 13 days after slaughter. Thirteen days post mortem the difference was only evident in the degradation of troponin T between IS and LL muscles (LL showed a greater degree of degradation). A higher level of fragmentation of muscle fibres was evident in muscle with higher degradation of troponin $\mathrm{T}$, namely in LL. The highest value of shear force according to the W-B test, i.e. the greatest toughness, was, however, found in this muscle. A similar level of degradation of troponin $\mathrm{T}$ and fragmentation of muscle fibres as LL was also shown by BF. In contrast, PM, with similar proteolysis of troponin $\mathrm{T}$, had only extremely low fragmentation of muscle fibres. The degree of fragmentation of muscle fibres cannot, therefore, explain differences in toughness (values of shear force according to the W-B test) between various muscles. There are evidently other factors, such as SL and IMF, that have a greater influence on the tenderness (or toughness) of meat.

A negative relationship between the shear force value and SL was found with a view to correlation between the shear force value and other variables in the analysed muscles. The same relationship also applied to the shear force value and the IMF content. A number of various factors therefore contribute to the tenderness of fresh meat. In certain kinds of meat (muscles), such as sirloin and silverside for example, a role is played by proteolytic processes post mortem, and the cold storage of such meat after slaughter (meat ageing) is worthwhile. The given effect of these ageing processes is, however, only small in tenderloin (Veiseth-Kent et al. 2018). As Archile-Contreras et al. (2010) state, the great biological diversity of the skeletal muscles may be the reason for great variability between different muscles in the meat tenderness. There are even great differences between muscles with a view to the speed and degree of texture development under standardised processing conditions post mortem, with meat ageing improving tenderness in certain muscles and not in others. Aaslyng et al. (2018) recommend longer ageing of pork meat obtained from boars in comparison to meat from castrated individuals or gilts to balance out the differences in tenderness resulting from the differing IMF content.

\section{The influence of the appliance used on meat tenderness and cooking loss}

The various methods of cooking meat (boiling, roasting, grilling) involve two methods of heat transfer. Thermal energy transferred through air (roasting in a traditional oven or convection oven) or water (e.g. sous-vide in a water bath) involves a transfer by convection. When meat is in direct contact with the heat source, as it is during grilling on contact grills, we talk about a transfer by conduction. In such case a shorter period of time is required for the cooking of meat.

Fabre et al. (2018) tested samples of beef obtained from steers of the Aberdeen Angus breed. Steaks of a thickness of $2.54 \mathrm{~cm}$ were cooked using three methods. The meat was cooked in each appliance until an internal temperature of $71^{\circ} \mathrm{C}$ was attained. Roasting in a hot-air oven took place at $163{ }^{\circ} \mathrm{C}$, with the slices of meat being turned after an internal temperature of $40^{\circ} \mathrm{C}$ had been attained. The meat was cooked in aluminium trays with a metal grate for the duration of roasting. Boiling took place in a water bath set to $98 \pm 1{ }^{\circ} \mathrm{C}$, with the meat inserted into polyamide bags. Grilling took place on a singleside contact grill set to $200 \pm 20^{\circ} \mathrm{C}$, with the slices of meat being turned when an internal temperature of $40^{\circ} \mathrm{C}$ had been attained.

Steaks roasted in the oven showed the highest values of shear force measured by W-B test in all kinds of meat tested (Table 1). Significant differences $(P<0.05)$ were found in the tenderness of meat prepared in the oven as compared to the use of the contact grill. Samples of meat boiled in a water bath attained a tenderness whose shear force values were between those recorded for samples cooked in the oven and on the contact grill. They did not, however, differ significantly from the values obtained with the contact grill. 
Table 1. Mean values of Warner-Bratzler shear force (N) and cooking loss (\%) for three cooking methods (Fabre et al. 2018).

\begin{tabular}{llcccc}
\hline & Method & LT & ST & SM & BF \\
\hline W-B (N) & oven & $59.8^{\mathrm{b}}$ & $57.9^{\mathrm{b}}$ & $65.7^{\mathrm{b}}$ & $64.7^{\mathrm{b}}$ \\
& grill & $38.3^{\mathrm{a}}$ & $43.2^{\mathrm{a}}$ & $51.0^{\mathrm{a}}$ & $53.0^{\mathrm{a}}$ \\
& water bath & $50.0^{\mathrm{ab}}$ & $46.1^{\mathrm{a}}$ & $58.8^{\mathrm{ab}}$ & $56.9^{\mathrm{ab}}$ \\
Cooking loss (\%) & oven & $39.9^{\mathrm{c}}$ & $39.6^{\mathrm{b}}$ & $35.4^{\mathrm{b}}$ & $38.1^{\mathrm{b}}$ \\
& grill & $25.7^{\mathrm{b}}$ & $28.5^{\mathrm{a}}$ & $26.5^{\mathrm{a}}$ & $25.6^{\mathrm{a}}$ \\
& water bath & $16.0^{\mathrm{a}}$ & $25.0^{\mathrm{a}}$ & $25.0^{\mathrm{a}}$ & $23.2^{\mathrm{a}}$ \\
\hline
\end{tabular}

a,b,c different superscripts within the same column for the same parameter (W-B test, losses) show significant differences in values $(P<0.05)$; LT $-\mathrm{m}$. longissimus thoracis; $\mathrm{ST}-\mathrm{m}$. semitendinosus; $\mathrm{SM}-\mathrm{m}$. semimembranosus; $\mathrm{BF}$ - biceps femoris; W-B = Warner-Bratzler shear force test.

The cooking losses in the slices of meat in the hot-air oven (35.4-39.9\%) were considerably greater than those for the other two methods used (16.0-28.5\%). The reason for this was evidently the longer cooking time (120 min as opposed to $15 \mathrm{~min}$ ) in the oven and the time for which the samples of meat in the oven were exposed to a temperature band of $60-70{ }^{\circ} \mathrm{C}$. The results obtained corresponded to the conclusions formulated by Purslow et al. (2016) to the effect that meat loses volume and weight during cooking by expelling water. This change in the content of liquids is also accompanied by modification of the textural parameters of the meat that occur along with changes to proteins and fat caused by the action of heat.

Yancey et al. (2011) tested the cooking of ribeye steaks (m. longissimus thoracis) aged at $2{ }^{\circ} \mathrm{C}$ for $0,7,14,21,28$ and 35 days. The steaks were $2.5 \mathrm{~cm}$ thick $(\mathrm{n}=360)$ and cooked at temperatures of $65.5^{\circ} \mathrm{C}$ (medium-rare), $71.1{ }^{\circ} \mathrm{C}$ (medium) and $76.6^{\circ} \mathrm{C}$ (medium-well) in five different appliances:

1) A hot-air oven, preheated to $165^{\circ} \mathrm{C}$, cooked on a grate and turned at 35.0, 37.8 and $40.6{ }^{\circ} \mathrm{C}$ for endpoint temperatures of $65.5,71.1$ and $76.6^{\circ} \mathrm{C}$.

2) A gas-fired grill, the steaks turned every $4 \mathrm{~min}$ (a combination of convection and conduction heat transfer).

3) An open electric grill set to $182.2{ }^{\circ} \mathrm{C}$; the steaks turned every $4 \mathrm{~min}$ (conduction heat transfer - direct contact between the meat and the griddle).

4) A forced-air impingement oven set at $182.2{ }^{\circ} \mathrm{C}$ (a convection method of heat transfer).

5) A contact grill, conduction heat transfer.

Cooking was followed by cooling for $5 \mathrm{~min}$ at room temperature and weight losses were determined by weighing. The weight losses (Table 2 ) were considerably lower in the case

Table 2. Values of Warner-Bratzler shear force $(\mathrm{N})$ and cooking loss (\%) for various meat cooking methods (Yancey et al. 2011).

\begin{tabular}{lcc}
\hline Appliance used & W-B $(\mathrm{N})$ & Cooking loss $(\%)$ \\
\hline Hot-air oven & 32.0 & 31.5 \\
Forced-air oven & 33.3 & 29.9 \\
Open electric grill & 34.6 & 30.7 \\
Gas grill & 34.2 & 32.6 \\
Contact grill & 35.4 & 26.2 \\
\hline
\end{tabular}

There were no significant differences between the weight losses for various cooking technologies. of the use of the hot-air oven for a period of $23 \mathrm{~min}(32.0 \%)$ than those found by the cited Fabre et al. (2018) who found cooking losses of $39.9 \%$ after $120 \mathrm{~min}$. With the use of the contact grill, however, both studies showed similar weight loss results (Yancey et al. 2011: 26.2\%; Fabre et al. 2018: 25.7\%).

Weight loss in meat during cooking increases with the rising temperature (Purslow et al. 2016). Between 40 and $60^{\circ} \mathrm{C}$ 
muscle fibres shrink laterally, and the space between fibres thereby expands. Then, from 60 to $65{ }^{\circ} \mathrm{C}$, muscle fibres shrink mainly longitudinally, thereby causing considerable water losses. The extent of this contraction increases with increasing temperature (Baldwin 2012). During the testing of various methods of cooking pork meat (m. longissimus thoracis et lumborum), Becker et al. (2016) found that this longitudinal shrinkage amounted to $27.1 \%$ in the case of convection cooking (oven temperature $180{ }^{\circ} \mathrm{C}$, attained meat core temperature $80{ }^{\circ} \mathrm{C}$ ), while the corresponding figure at a temperature of $53{ }^{\circ} \mathrm{C}$ for 20 hours or $60{ }^{\circ} \mathrm{C}$ for $2 \mathrm{~h}$ was just 4.0 or $4.1 \%$, respectively. A temperature of $58{ }^{\circ} \mathrm{C}$ for $20 \mathrm{~h}$ caused a contraction of $7.1 \%$.

Lateral contraction amounted to $11.2 \%$ at $53{ }^{\circ} \mathrm{C}, 13.8 \%$ at $58{ }^{\circ} \mathrm{C}$ and $5.5 \%$ at $60{ }^{\circ} \mathrm{C}$. The figure for the traditional method was $9.8 \%$ (no significant difference was found during comparison of traditional cooking with the action of a temperature of $53{ }^{\circ} \mathrm{C}$ for $20 \mathrm{~h}$ ). The traditional cooking method also showed the largest water loss, which ranged from $17.4 \%$ at $60{ }^{\circ} \mathrm{C}$ to $37.2 \%$ at $80{ }^{\circ} \mathrm{C}$ (Becker et al. 2016). The shrinkage of muscle fibres is caused by the shrinking of myofibrillar proteins which have a preserved structure during meat cooking until their denaturation occurs.

\section{Survival of Salmonella during the cooking of meat}

The elimination of bacterial cells during the cooking of meat depends on a number of factors, such as the thermal resistance of the bacteria present, the speed of heat transfer, the composition of the product (fat content, $\mathrm{pH}$ value, etc.) and the size and shape of the cooked meat. In their review paper, Jarvis et al. (2016) stated D-values for Salmonella ( $\mathrm{D}$-value $=$ the time in minutes necessary at a given temperature to reduce the number of bacteria present by $90 \%$ ) for various kinds of poultry meat and various temperatures. The mean values of 24.0 min for $\mathrm{D}_{55}$ (i.e. at $55^{\circ} \mathrm{C}$ ), 3.83 min for $\mathrm{D}_{60}$ and just 0.10 minutes for $\mathrm{D}_{70}$ apply for chicken breast. Similar times apply for turkey breast at the same temperatures (24.1, 3.83 and 0.10). A slightly longer time $(28.6,6.79$ and 0.11$)$ is required for the devitalisation of Salmonella in duck meat. De Jonge 2019 stated a mean $\mathrm{D}_{70}$ value of 0.147 min (i.e. $8.8 \mathrm{~s}$ ) for Salmonella.

The survival or devitalisation of Salmonella is influenced by the fat present. $\mathrm{A}_{60}$ value of $4.83 \mathrm{~min}$ and $\mathrm{D}_{65}$ value of 0.415 min apply for minced chicken meat with a fat proportion of $2 \%$, while the corresponding values are higher for meat with a fat proportion of $12 \%-5.50 \mathrm{~min}$ for $\mathrm{D}_{60}$ and 0.502 for $\mathrm{D}_{65}$ (Jarvis et al. 2016). Similar values apply for minced beef. In experiments with the Salmonella strain Typhimurium DT104, $\mathrm{D}_{55}$ values of $21.98 \mathrm{~min}$ were found for minced beef with $19.1 \%$ fat, while the corresponding value was just $9.05 \mathrm{~min}$ for a fat proportion of $4.8 \%$. Similarly, the given times were $3.38 \mathrm{~min}$ $(19.1 \%$ fat $)$ and $0.57 \mathrm{~min}(4.8 \%$ fat $)$ for $\mathrm{D}_{61}$. If the temperature was further increased to $64{ }^{\circ} \mathrm{C}$, then $0.92 \mathrm{~min}$ was required for $90 \%$ Salmonella reduction, and just $0.16 \mathrm{~min}$ for leaner minced meat (Jarvis et al. 2016).

The $z$ value is an indicator of the sensitivity of bacteria to temperature (Huang et al. 2019). It expresses the increase in temperature (in ${ }^{\circ} \mathrm{C}$ ) required to reduce the D-value by $90 \%$ (i.e. a decimal reduction - e.g. from $30 \mathrm{~min}$ to $3 \mathrm{~min}$, from $3 \mathrm{~min}$ to $0.3 \mathrm{~min}$, etc.) while maintaining the same devitalisation (lethal) effect on the bacteria. A mean $z$ value of $7.30{ }^{\circ} \mathrm{C}$ applies for the meat of domestic ungulates and a value of $6.29^{\circ} \mathrm{C}$ for poultry meat in the case of Salmonella (Huang et al. 2019).

If poultry meat or oven-ready poultry foods are contaminated by Salmonella, then $10 \mathrm{CFU} / \mathrm{g}$ or even less is naturally considered a probable level of contamination. A higher number of CFU (100-1,000/g) means the multiplication of bacterial cells as a consequence of unsuitable storage at higher temperatures. Analysis of food-borne outbreaks has found that the number of Salmonella bacteria cells received by patients was of the order of $10^{6} \%$ person, though the infective dose was smaller in a number of cases (Jarvis et al. 2016). 
Roccato et al. (2015) analysed 65 samples of oven-ready meat products containing poultry meat (burgers, grilling sausages, kebabs, roulades) for the presence of Salmonella. Forty of these samples were positive. It is stated in the literature that certain strains of Salmonella are also capable of growing at a temperature of $54{ }^{\circ} \mathrm{C}$ and can therefore survive the cooking of foodstuffs (Jarvis et al. 2016).

Survival of Listeria monocytogenes during the cooking of meat

Roccato et al. (2015) stated that the recommended combination of temperature and time of $70{ }^{\circ} \mathrm{C}$ for $2 \mathrm{~min}$ reduces the number of $L$. monocytogenes bacteria, which are considered the vegetative bacteria most resistant to the action of heat, by more than $6 \log$ (Roccato et al. 2015). This combination is, therefore, effective generally in minimising the risk caused by the presence of pathogenic bacteria in foods. Lahou et al. 2015 also confirmed the higher thermal resistance of L. monocytogenes in comparison with the other main agents of food-borne diseases. They found $\mathrm{D}_{60}$ values (values given as mean \pm standard deviation) of $1.28 \pm 0.36 \mathrm{~min}$ for L. monocytogenes, $0.61 \pm 0.08$ for Salmonella spp., $0.84 \pm 0.13$ for $E$. coli $\mathrm{O} 157: \mathrm{H} 7$ and $0.40 \pm 0.14$ for Campylobacter jejuni in a liquid medium (BHI - Brain Heart Infusion broth or Bolton broth).

The thermal resistance of five strains of Salmonella spp. and five strains of L. monocytogenes in meat from chicken breast muscle (pieces of a weight of $5 \mathrm{~g}$ and thickness of $1.5 \mathrm{~cm}$ ) was tested in the experiment described by the authors Karyotis et al. (2017). Some of the meat was treated with a teriyaki marinade ( $\mathrm{pH} \mathrm{4.20)} \mathrm{for} 18 \mathrm{~h}$. All the samples of meat were vacuum packed following contamination with the tested bacteria $\left(10^{6}-10^{8} \mathrm{CFU} / \mathrm{g}\right)$. Cooking was performed using the sous-vide method at temperatures of $55,57.5$, and $60{ }^{\circ} \mathrm{C}$. The thermal resistance of Salmonella was clearly lower than that of listeria. A period of around $48 \mathrm{~min}$ (fresh meat) was required to reduce the number of bacterial cells of salmonella by $90 \%$ at a temperature of $55^{\circ} \mathrm{C}$, while the action of the same temperature for a period of $55 \mathrm{~min}$ was necessary in the case of $L$. monocytogenes. Thanks to the lower $\mathrm{pH}$ value, the marinating of meat increased the sensitivity of bacterial cells to the action of higher temperatures.

\section{Survival of STEC during the cooking of meat}

Fourteen confirmed cases and ten probable cases of infection caused by E. coli $\mathrm{O} 157: \mathrm{H} 7$ associated with a single place (restaurant A) were identified in Pennsylvania (USA) in 2013 (Torso et al. 2015). All the confirmed cases reported that they had eaten a hamburger at restaurant $\mathrm{A}$ at the time in question. Of these, $71 \%$ confirmed that the hamburger had been prepared "rare" or "medium". Conformity between isolates of E. coli O157:H7 obtained from patients and from samples taken at restaurant A was confirmed by laboratory methods. The beef meat was, with the greatest probability, contaminated before delivery to the restaurant.

Escherichia coli $\mathrm{O} 157: \mathrm{H} 7$ is the most frequent serotype in the STEC group. The EFSA recorded a total of 6,073 cases of illness caused by STEC in the monitored European states in 2017 (a year-on-year decline of 6.2\%). Isolates from the 0157 group were found to be the agent in $31.9 \%$ of confirmed cases (EFSA 2018). A low infective dose is characteristic of $E$. coli $\mathrm{O} 157: \mathrm{H} 7$ for humans and is quantified as mere 10-100 cells (Attenborough and Matthews 2000).

According to the authors of the above case study from the USA there are no guarantees that fresh beef is free of $E$. coli $\mathrm{O} 157: \mathrm{H} 7$, even when HACCP plans are properly applied (Torso et al. 2015). If meat contamination occurs, the bacteria present on the meat surface are reliably destroyed during cooking as the surface layers are exposed to high, and therefore adequate, temperatures. Nevertheless, if whole pieces of meat are minced, the bacteria on the meat surface get inside. This situation occurs during the preparation 
of burgers and similar products. The individual portions then require thorough cooking to ensure an adequate thermal effect throughout the entire mass of the product. "Rare" or "medium" cooking, during which the internal temperature does not reach the values required to devitalise $E$. coli $\mathrm{O} 157: \mathrm{H} 7$, does not suffice.

The United States Department of Agriculture (USDA) recommends the attainment of an internal temperature of $62.7^{\circ} \mathrm{C}$ maintained for $3 \mathrm{~min}, 65.5^{\circ} \mathrm{C}$ maintained for $2 \mathrm{~min}$ or $71.1{ }^{\circ} \mathrm{C}$ that need not be further maintained for the safe cooking of whole pieces of meat to ensure a fall in the number of Salmonella or E. coli O157:H7 of $10^{5}$ cells (Saha et al. 2018). Beef meat, meanwhile, reaches an internal temperature of $47-53{ }^{\circ} \mathrm{C}$ when cooked "rare" and $65-70{ }^{\circ} \mathrm{C}$ when cooked "well-done" (Kondjoyan et al. 2018).

During culinary preparation, the risk of surface bacteria getting inside the food does not arise merely during the mincing of meat. The use of "mechanical tenderising" is just as risky (Gill et al. 2008). This procedure is popular in North America and is also known in Europe. It consists of disrupting the integrity of IMCT and muscle fibres in individual pieces of meat; as a result, strong contractions of the structures of muscle fibres and connective tissue do not occur during cooking which makes the meat seem more tender and juicy. Mechanical tenderising is performed in two ways (Yang et al. 2017), either by means of a system of narrow blades that penetrate the pieces of meat crosswise, or by means of sharp discs that disrupt merely the surface layers of the meat. Minute steaks or "delicated" steaks are prepared in the latter way. These have also become more popular recently in view of their shorter cooking time.

The above-cited Yang et al. (2017) tested the survival of $E$. coli $\mathrm{O} 157: \mathrm{H} 7 \mathrm{in}$ slices of beef (minute steaks of a weight of around $125 \mathrm{~g}$ ) prepared on a griddle heated to $200{ }^{\circ} \mathrm{C}$. The slices of meat were artificially contaminated in three places with a cell content of around $10^{6}$ per place. The steaks were grilled for $4,6,8$ or $10 \mathrm{~min}$, being turned as many as four times during the whole cooking period. Cells of $E$. coli $\mathrm{O} 157: \mathrm{H} 7$ could be isolated from all samples and from each contaminated place if grilling lasted just $4 \mathrm{~min}$. The number of cells was reduced by 1 to $3 \log$ (i.e. by $90-99.9 \%$ ), regardless of the frequency with which the meat was turned during preparation. The reduction in the number of bacteria was greater, amounting to 4-5 log, when the meat was grilled for $6 \mathrm{~min}$ and turned once or twice or grilled for $8 \mathrm{~min}$ and turned once. When a preparation time of $6 \mathrm{~min}$ with the meat turned three times during this period, 8 min with the meat turned twice, or 10 min with the meat turned just once was chosen, the complete devitalisation of E. coli O157:H7 occurred in most places, though these bacteria could still be isolated from a number of samples. Only a preparation method involving $10 \mathrm{~min}$ with turning at least twice or $8 \mathrm{~min}$ with turning at least three times resulted in a reduction by more than $5 \log$ and the tested strains of $E$. coli O157:H7 could no longer be obtained from the samples of cooked meat. The same results (i.e. total destruction of the bacterial strains used) were obtained when slices of meat were grilled until an internal temperature of $71{ }^{\circ} \mathrm{C}$ was attained (Yang et al. 2017).

If, according to Huang et al. (2019), the above-mentioned $z$ value is an indicator of the sensitivity of bacteria to temperature, then E. coli $\mathrm{O} 157: \mathrm{H} 7$ bacteria are less resistant to the action of higher temperatures than Salmonella. A $z$ value of $5.46{ }^{\circ} \mathrm{C}$ was determined for beef and a value of $5.65^{\circ} \mathrm{C}$ for other kinds of meat (Huang et al. 2019).

\section{Meat cooking and attaining a suitable temperature}

The cited study by Yang et al. (2017) confirms that attention must be paid to the cooking of meat from the viewpoint of food safety and that the attainment of a temperature of $70{ }^{\circ} \mathrm{C}$ in the middle of the product is not always a matter of course during cooking by consumers. Belgian researchers tested the survival of L. monocytogenes, Salmonella spp., Campylobacter jejuni and E. coli O157:H7 during the frying of various kinds of fresh meat and ready-to-cook meat products in a frying pan (Lahou et al. 2015). Steaks, fillets and 
burgers were fried for several minutes (from 2 to $10 \mathrm{~min}$ ) on each side and then left for 3-5 min on a plate at room temperature. A core temperature of $70^{\circ} \mathrm{C}$ was achieved in just 24 out of 36 cases of cooking various kinds of fresh meat. A core temperature of $70{ }^{\circ} \mathrm{C}$ was not attained in 5 out of 12 cases during testing of the frying of burgers. In the experiment, samples of meat and ready-to-cook meat products were artificially contaminated with the above pathogenic bacteria to a level of $10^{4} \mathrm{CFU} / \mathrm{g}$. The greatest quantitative detection of the used pathogens was recorded in pork burgers (40\%), followed by lamb $(20 \%)$ and beef $(13 \%)$ steaks (Lahou et al. 2015). Intact slices of meat were prepared "rare" ( 2 min on each side), "medium" (4 min on each side) and "well-done" (6.5 min on each side) in the frying pan. Residual detection of pathogens was possible at all degrees of preparation: $18 \%$ "well-done", 71\% "medium" and as much as 90\% "rare". When samples were multiplied in corresponding liquid media after cooking, L. monocytogenes was successfully isolated from 7 out of 30 samples (23\%), Salmonella spp. from 3 out of 29 samples (10\%), C. jejuni from 8 out of 30 samples $(26.7 \%)$ and E. coli $\mathrm{O} 157: \mathrm{H} 7$ from 2 out of 29 samples $(7 \%)$ cooked "well-done". It is evident from these results that not even "well-done" cooked meat guaranteed the devitalisation of pathogenic bacteria at a level of $6 \log$. The authors deduce that a temperature/time combination of $70{ }^{\circ} \mathrm{C} / 2 \mathrm{~min}$ is not necessarily attained during the cooking of meat at home even when the meat looks to have been adequately cooked. On the other hand, even when this combination is attained, this did not mean the complete devitalisation of the present agents of alimentary infections. During frying the surface of meat is exposed to temperatures of around $115-120^{\circ} \mathrm{C}$ (Lahou et al. 2015). If the bacteria present survive, a part of them probably penetrate from the meat surface to deeper layers that are not exposed to such high temperatures as the surface during frying. This is also the case for burgers, in which bacteria from the surface of the meat get inside as a result of mincing. If, however, bacteria survived the demonstrable action of a temperature of $70{ }^{\circ} \mathrm{C}$, they have to have developed defence mechanisms that protected them against the action of a high temperature.

De Jonge (2019) described an experiment in which chicken breast cutlets (140-175 g) and pork fillets (100-175 g) were artificially contaminated with $1 \mathrm{ml}$ cultures of Salmonella $\left(10^{9} \mathrm{CFU} / 1 \mathrm{ml}\right)$, left overnight at $5^{\circ} \mathrm{C}$ and then immersed in 41 of hot water $\left(\mathrm{t}>90^{\circ} \mathrm{C}\right)$ for $0-18 \mathrm{~min}$. The meat surface reached a temperature of $70^{\circ} \mathrm{C}$ in $30 \mathrm{~s}$. A temperature of $90^{\circ} \mathrm{C}$ was measured after $1 \mathrm{~min}$ and Salmonella was still detectable. A longer period of survival of Salmonella was recorded on poultry meat compared to pork. The author explains it by the lower thermal conductivity of chicken breast cutlets in comparison with pork meat. The adherence of bacteria to the meat increased their thermal resistance.

The survival of bacterial cells was possible due to changes in thermal resistance during the first $35 \mathrm{~s}$ after immersion in hot water. Water loss and decrease in the cell volume occurred with the rapid increase in temperature, resulting also in an increase in thermal resistance. Bacterial cell water loss may have caused reduction of the heat transfer coefficient in the cell cytoplasm. This may explain the extremely high thermal resistance of bacterial cells that were capable of surviving ordinarily lethal temperatures (de Jonge 2019). The cited author describes the curve of survival of bacterial cells by a logarithm of the kinetics of linear inactivation. During a certain unit of time $90 \%$ of the bacteria present die, another $9 \%$ will die twice as slowly, and $0.9 \%$ at a rate three times slower. Slower devitalisation may be explained in part by the synthesis of heat shock proteins. The aforementioned loss of water from the cytoplasm also assists the non-linear (two-phase) survival. The author states that the properties of thermal resistance of bacterial cells may change unpredictably in connection with the method of cooking (de Jonge 2019).

In conclusion, during the cooking of meat the shear force value falls from $50{ }^{\circ} \mathrm{C}$ to $65^{\circ} \mathrm{C}$ (in other words, meat becomes tenderer) and then increases again up to $80^{\circ} \mathrm{C}$. Temperatures above $60{ }^{\circ} \mathrm{C}$ up to $80{ }^{\circ} \mathrm{C}$ cause an increase in toughness due to the increasing firmness 
(consistency) of the muscle fibres resulting from their shrinkage, particularly longitudinally. The gelatinisation of sarcoplasmic proteins occurs when the meat temperature is increased up to $65{ }^{\circ} \mathrm{C}$ and the gel becomes tenderer - it breaks easily under the pressure of teeth - for which reason meat tenderness increases at temperatures between 50 and $65{ }^{\circ} \mathrm{C}$.

A proportion of the free water held by capillary forces in the space between the actin and myosin filaments of the myofibrils is expelled by the shrinkage of muscle fibres. The intensity of shrinkage caused by heat is expressed in the size of weight losses in the meat during cooking.

In terms of food safety, the attainment of an internal temperature of $70{ }^{\circ} \mathrm{C}$ lasting at least $2 \mathrm{~min}$, or a combination of temperature and time with the same thermal effect, is recommended for an adequate cooking of meat. This temperature is not, however, always attained with the use of many meat cooking methods, such as grilling or frying. This presents the risk of survival of food-borne agents present, such as Salmonella or STEC.

Increased thermal resistance, and thereby the survival of part of the bacteria present (e.g. Salmonella spp.), has been recorded in experiments during extremely rapid meat cooking, even after the short-term action of a temperature of $90{ }^{\circ} \mathrm{C}$. Nevertheless, the majority of the bacterial population (at least 90\%) was destroyed by thermal treatment. Since a certain minimum (infective) dose of bacteria is required to induce a food-borne disease, suitable measures to protect consumers must be adopted. First and foremost, this means respecting the principles of correct hygiene practice starting with the fattening of animals (the cleanliness of the body surface), taking in carcass processing and meat cutting and packing, and ending in distribution to the end consumer.

Observation of the refrigeration chain and assurance of the maximum temperature of meat according to the requirements of European legislation (i.e. fresh meat of domestic ungulates max. $7{ }^{\circ} \mathrm{C}$, poultry meat max. $4{ }^{\circ} \mathrm{C}$, minced meat max. $2{ }^{\circ} \mathrm{C}$ and chilled meat preparations max. $4{ }^{\circ} \mathrm{C}$ ) is critical. The latest knowledge indicates that, in the case of meat cross contamination by food-borne agents, their population is in the order of $10^{1}-10^{2} \mathrm{CFU} / \mathrm{cm}^{2}$ or $\mathrm{g}$. If they do not multiply as a result of a higher environmental temperature, the population of pathogenic bacteria present is then reliably eliminated during adequate cooking, either entirely or to an amount that does not suffice to induce illness.

\section{Acknowledgements}

This work was supported by the Ministry of Agriculture (grant QK1920190).

\section{References}

Aaslyng MD, Jensen H, Karlsson AH 2018: The gender background of texture attributes of pork loin. Meat Sci 136: $79-84$

Archile-Contreras AC, Mandell IB, Purslow PP 2010: Disparity of dietary effects on collagen characteristics and toughness between two beef muscles. Meat Sci 86: 491-497

Attenborough M, Matthews KR 2000: Food safety through the meat supply chain. J Appl Microbiol 88: $144-148$

Baldwin DE 2012: Sous vide cooking: A review. Int J Gastron Food Sci 1: 15-30

Becker A, Boulaaba A, Pingen S, Krischek C, Klein G 2016: Low temperature cooking of pork meat - Physicochemical and sensory aspects. Meat Sci 118: 82-88

De Jonge R 2018: Predictable and unpredictable survival of foodborne pathogens during nonisothermal heating. Int J Food Microbiol 291: 151-160

Dominguez-Hernandez E, Salaseviciene A, Ertbjerg P 2018: Low-temperature long-time cooking of meat: Eating quality and underlying mechanisms. Meat Sci 143: 104-113

EFSA 2017: The European Union summary report on trends and sources of zoonoses, zoonotic agents and food-borne outbreaks in 2016. EFSA J 2017 15: 5077

EFSA 2018: The European Union summary report on trends and sources of zoonoses, zoonotic agents and food-borne outbreaks in 2017. EFSA J 2017 16: 5500

Fabre R, Dalzotto G, Perlo F, Bonato P, Teira G, Tisocco O 2018: Cooking method effect on Warner-Bratzler shear force of different beef muscles. Meat Sci 138: 10-14 
Gill CO, Uttaro B, Badoni M, Zawadski S 2008: Distributions of brine and bacteria in beef primal cuts injected with brine without, or before or after mechanical tenderizing. Meat Sci 79: 181-187

Huang L, Hwang CA, Fang T 2019: Improved estimation of thermal resistance of Escherichia coli O157:H7, Salmonella spp., and Listeria monocytogenes in meat and poultry - The effect of temperature and fat and A global analysis. Food Contr 96: 29-38

Huff-Lonergan E, Zhang W, Lonergan SM 2010: Biochemistry of post-mortem muscle - Lessons on mechanisms of meat tenderization. Meat Sci 86: 184-195

Hulánková R, Kameník J, Saláková A, Závodský D, Borilova G 2018: The effect of dry aging on instrumental, chemical and microbiological parameters of organic beef loin muscle. LWT 89: 559-565

Jarvis NA, O’Bryan CA, Dawoud TM, Park SH, Kwon YM, Crandall PG, Ricke SC 2016: An overview of Salmonella thermal destruction during food processing and preparation. Food Contr 68: 280-290

Karyotis D, Skandamis PN, Juneja VK 2017: Thermal inactivation of Listeria monocytogenes and Salmonella spp. in sousvide processed marinated chicken breast. Food Res Int 100: 894-898

Kondjoyan A, Portanguen S, Duchène C, Mirade PS, Gandemer G 2018: Predicting the loss of vitamins B3 (niacin) and B6 (pyridoxamine) in beef during cooking. J Food Eng 238: 44-53

Lahou E, Wang V, De Boeck E, Verguldt E, Geeraerd A, Devlieghere, Uyttendaelle M 2015: Effectiveness of inactivation of foodborne pathogens during simulated home pan frying of steak, hamburger or meat strips. Int J Food Microbiol 206: 118-129

Latorre ME, Velázquez DE, Purslow PP 2018: The thermal shrinkage force in perimysium from different beef muscles is not affected by post-mortem ageing. Meat Sci 135: 109-114

Li S, Ma R, Pan J, Lin X, Dong Y, Yu C 2019: Combined effects of aging and low temperature, long time heating on pork toughness. Meat Sci 150: 33-39

Purslow PP, Oiseth S, Hughes J, Warner R 2016: The structural basis of cooking loss in beef: Variations with temperature and ageing. Food Res Int 89: 739-748

Regulation (EC) No 853/2004 of the European Parliament and of the Council of 29 April 2004 laying down specific hygiene rules for food of animal origin

Roccato A, Uyttendaele M, Cibin V, Barrucci F, Cappa V, Zavagnin P, Longo A, Ricci A 2015: Survival of Salmonella Typhimurium in poultry-based meat preparations during grilling, frying and baking. Int J Food Microbiol 197: 1-8

Saha J, Jaroni D, Nelson J, Willoughby C, McDaniel C, Jadeja R 2018: Influences of weight and thickness on cooking time required for various mechanically tenderized beef steaks to reach minimum safe internal temperature without resting. LWT 110: 365-369

Torso LM, Voorhees RE, Forest SA, Gordon AZ, Silvestri SA, Kissler B, Schlackman J, Sandt CH, Toma P, Bachert J, Mertz KJ, Harrison LH 2015: Escherichia coli O157:H7Outbreak Associated with Restaurant Beef Grinding. J Food Protect 78: 1272-1279

Veiseth-Kent E, Pedersen ME, Rønning SB, Rødbotten R 2018: Can postmortem proteolysis explain tenderness differences in various bovine muscles? Meat Sci 137: 114-122

Yancey JWS, Wharton MD, Apple JK 2011: Cookery method and end-point temperature can affect the WarnerBratzler shear force, cooking loss, and internal cooked color of beef longissimus steaks. Meat Sci 88: 1-7 